\title{
Investigating the physicochemical, sensory and microbial properties of plant-based protein products (meat-free burgers) formulated using various Vicia ervilia (L.) Willd. protein isolates
}

\author{
${ }^{1}$ Department of Food Science \& Technology, Sabzevar Branch, Islamic Azad University, Sabzevar, Iran \\ ${ }^{2}$ Razi Herbal Medicines Research Center, Lorestan University of Medical Sciences, Khorramabad, Iran \\ ${ }^{3}$ Khorasan Razavi Agricultural and Natural Resources Research and Education Center, Mashhad, Iran
}

Masoom Hatamikia ${ }^{1}$, Amir Hossein Elhamirad*1, Rouhollah Heydari ${ }^{2}$ Parvin Sharayei $^{3}$ \& Elham Azarpazhooh $^{3}$

\section{Article history}

Received: 24 April 2019

Accepted: 20 May 2019

Published: 29 July 2019

\section{Publisher}

Horizon e-Publishing Group

\section{* Correspondence}

Amir Hossein Elhamirad

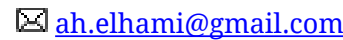

\begin{abstract}
The present study investigated the effect of using various protein isolates of Vicia ervilia (L.) Willd. (Bitter vetch; Family: Fabaceae) in formulating plant burgers on physicochemical, sensory and microbial properties of the resulting plant-based protein products. The results indicated that the plant-based protein products in the formulation of which protein isolates produced based on salt extraction methods were used, had higher rates of protein, fat and oil. On the contrary, they had lower rates of carbohydrate and moisture in contrast to the plant-based protein products formulated using protein isolates produced based on isoelectric precipitation methods. The reason for the high amount of fat and protein in these treatments can be attributed to the isolates' production conditions, high amount of oil diffused from the product in contrast to low oil retention and absorption capacity and low level of the measured moisture in comparison with the high protein content. In the current century, due to the uneven human population growth as well as the limited growth of animal resources, the debate about protein deficiency is particularly important in developing societies. Efforts for finding abundant and cheap herbal sources of protein have led to various researches regarding the use of some such less-known legumes in developing countries. In this regard, different protein isolates of Vicia ervilia have been used in the formulation of vegetable burgers to produce a new, inexpensive and productive plant protein product in the food industry.
\end{abstract}

Keywords: Vicia ervilia protein isolates, protein extraction, plant-based protein products' formulation, meat-free burgers

Citation: Hatamikia M, Elhamirad AH, Heydari R, Sharayei P, Azarpazhooh E. Investigating the physicochemical, sensory and microbial properties of plant-based protein products (meat-free burgers) formulated using various Vicia ervilia (L.) Willd. protein isolates. Plant Science Today 2019; 6(3):346-355. https://doi.org/10.14719/pst.2019.6.3.563

Copyright: (C) Hatamikia et al (2019). This is an open-access article distributed under the terms of the Creative Commons Attribution License, which permits unrestricted use, distribution, and reproduction in any medium, provided the original author and source are credited (https://creativecommons.org/licenses/by/4.0/).

Indexing: Plant Science Today is covered by Scopus,Web of Science, BIOSIS Previews, ESCI, CAS, AGRIS, CABI, Google Scholar, etc. Full list at http://www.plantsciencetoday.online

\section{Introduction}

Legumes are enumerated amongst the most important plant sources rich in proteins and valuable nutritional biogenic compounds can be prepared from them when combined with cereals for the fact that they contain a considerable amount of high-grade protein ( $17 \%$ to $38 \%)$. The protein 
rate in legumes' crude grains is two to three times higher than that of the cereals' (10\% to $15 \%)$. Thus, legumes can be used as rich sources of protein in the production of plant protein byproducts in the form of flour (50\%-65\% protein), concentrates (65\%-90\% protein) and/or protein isolates (over 90\%) (1). Vicia ervilia, commonly termed bitter vetch, belongs to legume family and the grains of this plant look red lentil when broken (2).

According to the producibility of this plant in Iran and its high percentage of protein content, its flours and protein byproducts can be evaluated in terms of performance characteristics and usability in food industry (3). Protein is considered as one of the most substantial nutrients in the living beings' nourishment and it can be supplied from two sources of plant-based and animalbased.

Nowadays, the demands are growing in food industry for using plant-based proteins as animal protein substitutes in the new products' formulation that can lead to the production of value-added foodstuff in lower prices (4). It is extremely important to provide suitable foodstuff that are balanced also in terms of nutrients.

Amongst the foodstuff, leguminous grains provide a high level of protein and carbohydrate hence, they are envisioned as appropriate resources of energy. (5). Besides, its good nutritional value also plays an important functional role in the formulation of the food products. The proteins' functional properties are indeed a set of their inherent physicochemical characteristics that influence the protein behavior in processing, production, storage and preparation systems. (6). Functional properties are considered as a critical scale for protein acceptance in food processing and it depends on the physicochemical and structural properties of the proteins. This property influences the food texture and its sensory traits and it is considered as a necessary factor in the production of sweeties, drinks, spices, meat products, extruded products and ready snacks (1). To maintain moisture and create a good texture in the meat products, bakery products and gel-like products, the protein's ability of retaining and absorbing water is of utmost importance $(8,9)$. However, no comprehensive and thorough study has been conducted on Vicia ervilia, as a plant from lentils and legume family, with regard of to the effect of various methods of protein extraction from Vicia ervilia in the formulation of plant-based protein products (meat-free burgers). Thus, the present study aimed to evaluate the effect of using Vicia ervilia's protein isolates extracted based on various protein extraction methods (acidic and alkaline extraction-sequestration in isoelectric point, salt-based extraction, dialysis and micelles sequestration) on the physicochemical, microbial and sensory properties of the plant-based protein products.

\section{Materials and Methods}

\section{The technology and methods used to extract protein from Vicia ervilia}

One of the advantages of using the technique of sediment based on the isoelectric point is that this method can effectively eliminate some antinutritional components (10). The process of producing the protein isolate using the method of alkaline extraction-sediment at the isoelectric point includes water extracting of soluble proteins from flour or meal, separating the insoluble residues from the water phase, sedimentation protein at the isoelectric point (protein clot formation), separating the protein clot from the water phase, washing and drying (11). Extracting using salt produces an isolate that contains both globulins and albumens (12, 13). Extracting by miscella sediment usually results in forming a protein isolate that is in the form of miscella and is fixed by hydrogen bands (14) and includes both albumin and globulin proteins and has less denatured and damaged proteins than the method of sediment at the isoelectric point (15).

\section{Preparing the fatless flour of Vicia ervilia}

In this study, Vicia ervilia was provided from the Agricultural Jihad Organization of Lorestan province. Then, they were milled by a laboratory mill. For uniformity of the resulted flour particles, the milled flour was sifted by screen of $1 \mathrm{~mm}$, and maintained at the refrigerator temperature until being used. In order to prepare the fatless flour of $V$. ervilia, the fat of the resulted screened and uniformed flour with a ratio of $1: 3$ of weightvolume removed using the normal hexane-solvent. So, in order to remove the fat completely, the mixture was placed on a magnetic mixing with rotation of $500 \mathrm{rpm}$ for 40 minutes. This process was repeated twice to extract the oil completely. For smoothing and separating the normal hexane solvent, Whatman filter paper was used and then placed under hood for 18 hours to dry and separating the normal hexane completely, and finally, the fatless flour of $V$. ervilia was maintained in closed containers in a refrigerator at $4^{\circ} \mathrm{C}$, for the next stages of producing the protein isolates by different methods of protein extraction $(5,16)$.

\section{Producing the protein isolates of Vicia ervilia using different methods of protein extraction}

Acidic extraction-sedimentation at isoelectric point: 100 grams of fatless flour of Vicia ervilia with weight-volume 1:15 ratio was mixed with deionized water. Then, its $\mathrm{pH}$ was reached at 2.5 by hydrochloric acid normal. The mixture (suspension) was placed on the magnetic mixing with rotation of $500 \mathrm{rpm}$ at the room temperature for 1 hour so that the protein becomes completely soluble and separates from non-protein compounds; then the mixture was centrifuged at 
Table 1. Chemical characteristics of the various plant-based protein isolates used in the formulation of plant-based protein products $(\mathrm{gm} / 100 \mathrm{~g})$

\begin{tabular}{|c|c|c|c|c|c|}
\hline $\begin{array}{l}\text { Plant-based protein isolate used in the } \\
\text { formulation }\end{array}$ & $\begin{array}{c}\text { Quantity of } \\
\text { plant-based } \\
\text { protein isolate } \\
\text { used in } \\
\text { formulation }(\mathrm{kg})\end{array}$ & Protein & Fat & Carbohydrate Moisture & Ash \\
\hline Soya protein isolate (evidence) & 9.5 & $91.52 \pm 0.45^{\mathrm{d}}$ & $0.250 \pm 0.03^{\mathrm{e}}$ & $1.85 \pm 0.20^{\mathrm{c}} 3.75 \pm 0.7^{\mathrm{b}}$ & $2.67 \pm 0.4^{b}$ \\
\hline V. ervilia protein isolate: salt/dialysis & 9.5 & $96.92 \pm 0.06^{\mathrm{a}}$ & $1.31 \pm 0.01^{\mathrm{a}}$ & $0.54 \pm 0.01^{\mathrm{e}} 4.65 \pm 2.5^{\mathrm{a}}$ & $4.25 \pm 1.5^{\mathrm{a}}$ \\
\hline V. ervilia protein isolate: micelles-sequestration & 9.5 & $94.63 \pm 0.18^{\mathrm{b}}$ & $1.01 \pm 0.02^{\mathrm{b}}$ & $1.07 \pm 0.04^{\mathrm{d}} 4.47 \pm 2.5^{\mathrm{a}}$ & $4.03 \pm 1.5^{\mathrm{a}}$ \\
\hline $\begin{array}{l}\text { V. ervilia protein isolate: acidic-sequestration in } \\
\text { isoelectric point }\end{array}$ & 9.5 & $92.43 \pm 0.21^{\mathrm{c}}$ & $0.67 \pm 0.01^{\mathrm{c}}$ & $4.35 \pm 0.12^{\mathrm{b}} 4.32 \pm 2.5^{\mathrm{a}}$ & $3.79 \pm 1.5^{\mathrm{a}}$ \\
\hline $\begin{array}{l}\text { V. ervilia protein isolate: alkaline-sequestration } \\
\text { in isoelectric point }\end{array}$ & 9.5 & $89.33 \pm 0.1^{\mathrm{e}}$ & $0.4 \pm 0.01^{\mathrm{d}}$ & $8.58 \pm 0.15^{\mathrm{a}} 4.18 \pm 2.5^{\mathrm{a}}$ & $3.87 \pm 1.5^{\mathrm{a}}$ \\
\hline
\end{tabular}

Numbers with at least one common letter are not statistically significant $(\mathrm{P}<0.05)$.

Table 2. Chemical properties of the other components (raw materials) used in the formulation of the plant-based protein products $(\mathrm{g} / 100 \mathrm{~g})$

\begin{tabular}{|c|c|c|c|c|c|c|}
\hline $\begin{array}{l}\text { Other components (raw } \\
\text { materials) of the } \\
\text { formulation }\end{array}$ & $\begin{array}{l}\text { Quantity used in } \\
\text { formulation (kg) }\end{array}$ & Protein & Fat & Carbohydrate & Moisture & Ash \\
\hline Water & 35.0 & - & - & - & $100 \pm 0.00$ & - \\
\hline Wheat flour & 10.5 & $12.3 \pm 0.3$ & $1.2 \pm 0.1$ & $71.8 \pm 0.6$ & $13.2 \pm 0.30$ & $1.2 \pm 0.10$ \\
\hline Onion & 23.0 & $0.8 \pm 0.1$ & - & $8.92 \pm 0.3$ & $89.3 \pm 0.90$ & $0.7 \pm 0.06$ \\
\hline Roasting flour & 02.5 & $11.8 \pm 0.2$ & $3.3 \pm 0.2$ & $72.6 \pm 0.7$ & $11.2 \pm 0.20$ & $0.72 \pm 0.08$ \\
\hline Gluten & 04.5 & $79.8 \pm 0.7$ & $1.1 \pm 0.1$ & $9.3 \pm 0.3$ & $8.1 \pm 0.20$ & $0.91 \pm 0.09$ \\
\hline Plant oil & 12.0 & - & $100 \pm 0.0$ & - & - & - \\
\hline Condiment & 1.50 & $3.8 \pm 0.3$ & $1.9 \pm 0.1$ & $37.5 \pm 0.4$ & $9.7 \pm 0.2$ & $6.8 \pm 0.30$ \\
\hline Salt & 1.50 & - & - & - & $0.2 \pm 0.01$ & $99.8 \pm 0.60$ \\
\hline
\end{tabular}

Numbers with at least one common letter are not statistically significant $(\mathrm{P}<0.05)$.

$4^{\circ} \mathrm{C}$ for 20 minutes in $4500 \mathrm{~g}$. Finally, the supernatant was collected. The resulted refuse was re-suspended by de-ionized water with a weightvolume ratio of $1: 5$, and its $\mathrm{pH}$ was set again at $\mathrm{pH}=2.5$ with hydrochloric acid 1 molar, and stirred at the room temperature for 45 minutes and finally re-centrifuged under the same conditions. The two supernatants resulted from centrifuging were mixed and their $\mathrm{pH}$ was set at 5.4 (isoelectric point and protein sedimentation) by sodium hydroxide 1 normal. Then, the mixture was centrifuged again in $4500 \mathrm{~g}$ at $4^{\circ} \mathrm{C}$ for 20 minutes to recover the sediment proteins. The clear supernatant was discarded and the resulted sediment (the resulted sediment protein) was collected. For higher purity, the recovered protein was washed in five steps and at each step for 5 minutes by centrifugation at $4500 \mathrm{~g}$ and with deionizedwater to set its $\mathrm{pH}$ at about 7. The resulted protein isolate was maintained in the closed containers at $-30^{\circ} \mathrm{C}$ and then dried by freeze dryer $(17,18)$.

Alkaline extraction- sedimentation at the isoelectric point: 100 grams of fatless flour of Vicia ervilia with weight-volume 1:15 ratio was mixed with de-ionized water. Then, its $\mathrm{pH}$ was reached at 11 by hydroxide sodium normal. The mixture (suspension) was placed on the magnetic mixing with rotation of $500 \mathrm{rpm}$ at the room temperature for 1 hour so that the protein becomes completely soluble and separates from non-protein compounds; then the mixture was centrifuged at $4^{\circ} \mathrm{C}$ for 20 minutes in 4500 g. Finally, the supernatant was collected. The resulted refuse was re-suspended by de-ionized water with a weight-volume ratio of $1: 5$, and its $\mathrm{pH}$ was set again at $\mathrm{pH}=11$ by hydroxide sodium 1 molar, and stirred at the room temperature for 45 minutes and finally re-centrifuged under the same conditions. The two supernatants resulted from centrifuging were mixed and their $\mathrm{pH}$ was set at 5.4 (isoelectric point and protein sedimentation) by acid hydrochloric 1 normal. Then, the mixture was centrifuged again at $4500 \mathrm{~g}$ at $4^{\circ} \mathrm{C}$ for 20 minutes to recover the sediment proteins. The clear supernatant was discarded and the resulted sediment (the resulted sediment protein) was collected. For higher purity, the recovered protein was washed in five steps and at each step for 5 minutes by help of centrifugation at $4500 \mathrm{~g}$ and with de-ionized water to set its $\mathrm{pH}$ at about 7 . The resulted protein isolate was maintained in the closed containers at $-30^{\circ} \mathrm{C}$ and then dried by freeze dryer $(5,16)$.

Dialysis- salt extraction: $100 \mathrm{gm}$ of fatless flour of $V$. ervilia with weight-volume 1:10 ratio was mixed with sodium phosphate buffer 0.1 molar (its $\mathrm{pH}$ should be set at 8) which contains $6.4 \%$ aqueous solution of potassium chloride. Then the mixture was stirred on the magnetic mixing with rotation of $500 \mathrm{rpm}$ at the room temperature for 24 hours and finally was centrifuged at $4^{\circ} \mathrm{C}$ for 20 minutes in $4500 \mathrm{~g}$ by a centrifuge having fridge. The supernatant was collected and dialyzed 
opposite the de-ionized water at $4^{\circ} \mathrm{C}$ and with $6-8$ kilo Dalton. The de-ionized water used should be renewed three times a day with fresh de-ionized water. Dialysis is performed for 72 hours until the direction of dialysis water (the used de-ionized water) reaches at about 20 micro Siemens per $\mathrm{cm}$ (equivalent to 2-2.5 mili Siemens per cm). After dialysis, the dialyzed was maintained in closed containers at $-30^{\circ} \mathrm{C}$ until it will be freeze dried (5, 16).

\section{Extraction by miscella sedimentation}

$100 \mathrm{gm}$ of fatless flour of $V$. ervilia in the solution 1normal of chloride sodium with weight-volume $1: 10$ ratio was mixed and stirred by the magnetic mixing with rotation of $500 \mathrm{rpm}$ at the room temperature for 2 hours. Then, it was centrifuged at $4^{\circ} \mathrm{C}$ for 20 minutes in $4000 \mathrm{~g}$ by a centrifuge having fridge. The supernatant was collected and diluted ten times by cold de-ionized water $\left(4^{\circ} \mathrm{C}\right)$ and placed at $4^{\circ} \mathrm{C}$ for 18 hours. Again, the solution was centrifuged at $4^{\circ} \mathrm{C}$ for 20 minutes in $4000 \mathrm{~g}$. After centrifugation, the resulted sediment was collected and maintained in closed containers at $30^{\circ} \mathrm{C}$ and then dried by freeze drier (solid drier).

\section{Method of preparing and producing plant-based protein products (plant burgers/meat-free burgers)}

To produce plant-based protein products formulated with the use of various protein isolates of $V$. ervilia and also soya bean protein isolates, both the $V$. ervilia and soybean protein isolates were firstly drenched in water for 24 hours. Then, the drenched protein isolates and all the powder materials used in the formulation (wheat flour, roasting flour, gluten, condiments and salt) were completely mixed according to the quantity defined and specified in a $25 \mathrm{~kg}$ mixer (Tables 1 and 2). Next, grated onion and oil were added to the mixer. At the end, cold $4^{\circ} \mathrm{C}$ water was gradually admixed with the mixture. After the perfect mixing of all the materials in the mixer for 10 minutes and an even paste was attained, the paste was subsequently molded in 100-gram (circular) molds following which the molded pastes were placed in freezer (cold storage) in $18^{\circ} \mathrm{C}$ for 24 hours so as to become completely frozen and solid and take the mold's shape.

\section{Methods of physicochemical and microbial test of the final product}

Moisture content was measured in $70^{\circ} \mathrm{C}$ under a pressure rate below $250 \mathrm{mmHg}$ using a vacuum oven (Memmert, Germany); the total ash content was measured in an electrical furnace in $550^{\circ} \mathrm{C}$ (Thermolyne F6000 Barnstead, Germany); the carbohydrate amount was measured based on Lane and Eynon method using Fehling solutions; the fat content was measured using a digital soxhlet device (Buchi, Swiss); and, the protein content was measured using a Macro Kjeldahl Apparatus (Buchi, Swiss). The total count of microorganisms was obtained in an agar medium; the molds and yeasts were counted in YGC agar medium; Escherichia coli counts were done in EC broth; Salmonella identification was carried out in peptone water culture medium; Staphylococcus aureus counts were obtained in Gioliti-Cantoni broth. Moreover, to measure the amount of oil diffused from the burger, the amounts of fat exuded by the product along with the extract oozed during the baking were collected. Then, to separate oil from the extract (moisture and other ingredients' contents), the obtained mixture was centrifuged. Finally, the separated oil was weighed and considered as the amount of oil diffused by the product.

\section{Method of sensory properties evaluation method (Panel Test)}

To investigate the sensory properties (color, flavor and texture), 30 tasters were selected based on degree diagnosis or quality level experiment to evaluate the specimens in terms of quality factors like color, flavor and texture perceivable via senses and rated them based on their preferences. Thirty identical samples were prepared of each treatment and presented to each of the tasters along with a specific table containing a five-scale hedonic scale so that they could complete the forms according to their own tastes and selected the superior sample based on their preferences. The tasters washed their mouths with water after each tasting measure. Scoring was the method of choice in this experiment and score five was assigned to optimum quality and score one was given for unfavourable quality. The completed tables included the consumers' general evaluations in the form of numerical values that were subjected to variance analyses.

\section{Statistical Analysis}

The present study investigated the effect of various $V$. ervilia protein isolates on the physicochemical, sensory and microbial properties of plant-based protein products (meat-free burgers) within the format of a completely random statistical design in three replications. The results were analyzed using SPSS software. All the methods of protein extraction from $V$. ervilia grain and plant-based protein productions and the related experiments were repeated thrice and the presented results are the means of the three replications.

\section{Results and Discussion}

Evaluation of physicochemical properties in plantbased protein products formulated with various Vicia ervilia's protein isolates

Fat: The analysis of the results of the present study indicated that the $V$. ervilia protein extraction method was significantly effective on the fat level of all the protein isolates (Table 1) hence the fat level of all the plant-based protein products 
Table 3. Physicochemical, microbial and sensory (organoleptic) characteristics of plant-based protein products formulated with various Vicia ervilia protein isolates

\begin{tabular}{|c|c|c|c|c|c|c|}
\hline Properties & $\begin{array}{l}\text { Acceptable } \\
\text { range of the } \\
\text { product } \\
\text { according to } \\
\text { Iran's national } \\
\text { standard } \\
\text { (Soya Burger) }\end{array}$ & $\begin{array}{l}\text { Products } \\
\text { containing soya } \\
\text { protein isolate } \\
\text { (evidence) }\end{array}$ & $\begin{array}{l}\text { Products } \\
\text { containing Vicia } \\
\text { ervilia protein } \\
\text { isolate / } \\
\text { salt/dialysis }\end{array}$ & $\begin{array}{l}\text { Products } \\
\text { containing Vicia } \\
\text { ervilia protein } \\
\text { isolate/ micelles }\end{array}$ & $\begin{array}{l}\text { Products } \\
\text { containing Vicia } \\
\text { ervilia protein } \\
\text { isolate/ acidic } \\
\text { sequestration }\end{array}$ & $\begin{array}{l}\text { Products } \\
\text { containing Vicia } \\
\text { ervilia protein } \\
\text { isolate/ alkaline } \\
\text { sequestration }\end{array}$ \\
\hline Protein (\%) & At least 10 & $14.18 \pm 0.98^{\mathrm{c}}$ & $15.34 \pm 1.20^{\mathrm{a}}$ & $14.89 \pm 1.23^{b}$ & $14.15 \pm 1.14^{\mathrm{c}}$ & $13.65 \pm 1.16^{\mathrm{d}}$ \\
\hline Fat (\%) & At most 12.5 & $12.48 \pm 0.08^{b}$ & $12.69 \pm 0.05^{\mathrm{a}}$ & $12.50 \pm 0.09^{\mathrm{b}}$ & $12.27 \pm 0.07^{\mathrm{c}}$ & $11.68 \pm 0.08^{\mathrm{d}}$ \\
\hline Carbohydrate (\%) & At most 13 & $12.69 \pm 0.32^{\mathrm{c}}$ & $11.82 \pm 0.29^{\mathrm{d}}$ & $12.73 \pm 0.32^{\mathrm{c}}$ & $13.23 \pm 0.31^{\mathrm{b}}$ & $13.97 \pm 0.40^{\mathrm{a}}$ \\
\hline Moisture (\%) & At most 63 & $58.24 \pm 1.47^{\mathrm{a}}$ & $56.45 \pm 1.87^{\mathrm{b}}$ & $56.97 \pm 1.59^{b}$ & $58.53 \pm 1.86^{\mathrm{a}}$ & $58.89 \pm 1.97^{\mathrm{a}}$ \\
\hline Ash (\%) & - & $2.23 \pm 0.13^{\mathrm{a}}$ & $2.91 \pm 0.15^{\mathrm{a}}$ & $2.57 \pm 0.11^{\mathrm{a}}$ & $2.02 \pm 0.15^{\mathrm{a}}$ & $2.15 \pm 0.14^{\mathrm{a}}$ \\
\hline Discharged oil (\%) & - & $2.66 \pm 0.06^{b}$ & $3.93 \pm 0.08^{a}$ & $3.88 \pm 0.09^{\mathrm{a}}$ & $2.63 \pm 0.05^{\mathrm{b}}$ & $2.59 \pm 0.08^{b}$ \\
\hline Flavor-tenderness & - & $4.89 \pm 0.03^{\mathrm{a}}$ & $5.00 \pm 0.03^{\mathrm{a}}$ & $4.92 \pm 0.02^{\mathrm{a}}$ & $4.23 \pm 0.03^{b}$ & $4.18 \pm 0.02^{b}$ \\
\hline Color & - & $4.90 \pm 0.01^{\mathrm{a}}$ & $4.89 \pm 0.03^{\mathrm{a}}$ & $4.83 \pm 0.01^{\mathrm{a}}$ & $4.85 \pm 0.03^{\mathrm{a}}$ & $4.87 \pm 0.02^{\mathrm{a}}$ \\
\hline $\begin{array}{l}\text { Texture-preservation } \\
\text { of the apparent } \\
\text { shape after cooking }\end{array}$ & - & $4.92 \pm 0.03^{\mathrm{a}}$ & $4.94 \pm 0.04^{\mathrm{a}}$ & $4.90 \pm 0.02^{\mathrm{a}}$ & $4.88 \pm 0.03^{\mathrm{a}}$ & $4.85 \pm 0.03^{\mathrm{a}}$ \\
\hline $\begin{array}{l}\text { Total microbe counts } \\
\text { (Cfu/g) }\end{array}$ & At most $10^{5}$ & $10^{2}$ & $10^{2}$ & $10^{2}$ & $10^{2}$ & $10^{2}$ \\
\hline $\begin{array}{l}\text { Escherichia coli } \\
\text { (Cfu/g) }\end{array}$ & Negative & Negative & Negative & Negative & Negative & Negative \\
\hline Salmonella (Cfu/g) & Negative & Negative & Negative & Negative & Negative & Negative \\
\hline $\begin{array}{l}\text { Mold and yeast } \\
\text { (Cfu/g) }\end{array}$ & At most 100 & 10 & 10 & 10 & 10 & 10 \\
\hline $\begin{array}{l}\text { Staphylococcus } \\
\text { aureus (Cfu/g) }\end{array}$ & At most 10 & Below 10 & Below 10 & Below 10 & Below 10 & Below 10 \\
\hline
\end{tabular}

(Table 3) were in a 5\% significance level $(\mathrm{P}<0.05)$. To produce protein isolates, $V$. ervilia grain flour was defatted using N-hexane solvent. Fat extraction from $V$. ervilia flour (defatting) caused an improvement in protein extraction for its reduction of the protein-lipid interactions. In addition to the defatting of $V$. ervilia grain flour, the residual fat of the defatted $V$. ervilia grain flour was removed in the course of various methods of protein extraction in such a way that the fat content of the entire isolates was reduced to less than $1.5 \%$. In the current research paper, the goal was replacing the plant-based $V$. ervilia's protein isolates for meat in formulating meat protein products and producing meat-free burgers containing $V$. ervilia's protein isolates corresponding to the properties and characteristics defined for soya-burger in Iran's National Standard. Since the entire components of the formulation were completely identical in such factors as the amounts and types of the physicochemical properties and the only difference lied in the various treatments in terms of the properties and characteristics of various protein isolates of $V$. ervilia and soybean in all of the manufactured products (various types of meatfree protein products produced with $V$. ervilia protein isolates) as well as the evidence treatment (soya burger), the differences in the fat amount of all treatments could be attributed to the amounts of fat in the $V$. ervilia protein isolates. The result is attributed to the aforesaid components used in the formulation of meat-free burgers as well as the application of completely similar production conditions. Due to the same reason, the present section investigated and explained the reasons for the differences in the amounts of fat in the various protein isolates of $V$. ervilia. As it can be seen in Table 1, the lowest and the highest fat contents pertained to the isolates produced based on alkaline method $(0.4 \% \pm 0.01 \%)$ and isolates produced based on salt-dialysis method $(1.31 \% \pm$ $0.01 \%$ ), respectively. One important reason for the lowness of fat in isolates produced based on alkaline method in contrast to the other methods was the changes resulting from severe denaturation in alkaline method and the higher likelihood of fat exudation from the isolate during the protein extraction process (19). One reason for the higher fat absorption capacity (protein's functional properties) of the isolates produced based on alkaline method in comparison to the other methods in the present study was possibly the low fat content of alkaline isolates hence their tendency to fat adsorption.

Carbohydrates: Due to the important effects of carbohydrate on the quality and sensory properties of the final product, the carbohydrate content of the final product (burger) is a very important consideration. As it can be seen in Table 2 , one of the most important starch ingredients existent in burger formulation was roasting flour and wheat flour. The large amount of starch in burger formulation caused it to become brittle in its texture, especially in its exterior surfaces which heightened the likelihood of its texture's disintegration during baking. Moreover, the high 
starch content caused the cooked burger to become dark brownish red and ungarnished in color for the intensification of the non-enzymatic browning reactions during cooking. On the other hand, low amount of starchy materials as one of the water adsorbents and preservatives in burger formulations caused the burger mixture (extract) not to take form during molding as a result of which the burger could not be cooked uniformly during cooking stage. The analysis of the obtained results was reflective of the idea that the type of $V$. ervilia grain's protein extraction method exerted a significant effect on the carbohydrate level of all the protein isolates (Table 1) hence carbohydrate level of all the plant-based protein products (Table 3 ) was in a $5 \%$ level $(\mathrm{P}<0.05)$. The differences in carbohydrate rates could be ascribed to the differences in the amount of carbohydrate in $V$. ervilia protein isolates due to the application of completely similar production methods as well as the identicalness of the amount and type of the physicochemical properties of all the components used in the formulation (except $V$. ervilia and soya protein isolates' characteristics). As it can be observed in Table 1, the highest and the lowest carbohydrate values obtained in the present study were respectively related to isolates separated based on alkaline method $(8.58 \% \pm 0.15 \%)$ and isolate produced based on salt-dialysis method $(0.54 \% \pm 0.01 \%)$. The highest reductions in carbohydrate in protein isolates had been correspondingly observed for salt-dialysis, micelles, acidic and alkaline extraction methods. One reason for the high carbohydrate content of isolates produced based on alkaline method as compared to the other methods was the changes resulting from the intensity of denaturation in alkaline method and the possibly higher exudation of non-protein materials like carbohydrates and fibers from $V$. ervilia grain (raw material) during the protein extraction process and remaining of these ingredients in the isolate (19). In addition, in higher $\mathrm{pH}$ values (alkaline method) and the nonprotein materials were more likely to exit the raw $V$. ervilia matter (20). This could also justify the higher carbohydrate content in alkaline extraction method. One reason for the high purity percentage of isolates produced based on salt-dialysis method in contrast to the other methods was the low content of such impurities as carbohydrates and fibers in isolates produced based on this method. It could be generally stated that cold protein extraction methods (salt-dialysis and micelles sequestration) in comparison to isoelectric pointbased sequestration (alkaline and acidic methods) prevented the denaturation of proteins as well as the reduction of the majority of the impurities like carbohydrates and also the increase in the purity percentage of isolates.

Protein: The analysis of the obtained results indicated that the type of the protein extraction from $V$. ervilia grain significantly influenced the protein level of all the isolates (Table 1) hence the protein level of all the plant-based protein products manufactured herein (Table 3 ) was in a $5 \%$ level $(\mathrm{P}<0.05)$. The final burger's protein rate was directly associated with the materials constituting the burger and the most important of them were protein ingredients existent in the formulation like protein isolates (with more than $90 \%$ protein) and gluten ( $70-80 \%$ protein). Due to the application of completely similar conditions as well as of the quantity and type of the physicochemical properties of all the components used in the formulation (except the characteristics of $V$. ervilia and soybean's protein isolates), the differences in the protein rates of all the treatments could be ascribed to the differences in protein contents of the various protein isolates of $V$. ervilia grain. As it can be seen in Table 1, the lowest and the highest protein rates in the present study pertained to isolates produced based on alkaline method $(89.33 \% \pm 0.1 \%)$ and isolates produced based on salt-dialysis method $(96.92 \% \pm$ $0.06 \%$ ). Generally, in the present study, the isolates extracted based on salt-dialysis method $(96.92 \% \pm$ $0.06 \%)$ and micelles sequestration $(94.63 \% \pm$ $0.18 \%)$ had considerably higher protein contents in respect to isolates produced based on isoelectric deposition such as acidic $(92.43 \% \pm 0.21 \%)$ and alkaline $(89.33 \% \pm 0.1 \%)$. In isoelectric deposition under alkaline conditions, protein extraction took place quite well due to the proteins' solubility in high $\mathrm{pH}$ values and proteins had been found sequestrated in $\mathrm{pH}$ values near isoelectric point (4.5-5.5). In salt-based extractions, various concentrations of salt were used for dissolving $V$. ervilia grain proteins. Proteins were sequestrated with the removal of salt during dialysis while the hydrated layers in the periphery of protein surface were disintegrated (21). In the current research paper, the results indicated that salt-based extraction (salt-dialysis and micelles) outperformed the other methods (isoelectric deposition) for the protein extraction from $V$. ervilia grain and gave higher concentrations of protein in the isolate. The high content of protein in salt-dialysis protein isolates in contrast to micelles deposition isolates could be ascribed to the differences in the protein extraction method, isolate preparation style and longer duration of protein extraction and renewing of the water used in salt-dialysis method. Moreover, in salt-dialysis extraction method, the used deionized water was replaced with fresh deionized water thrice a day and considering the very good solubility of albumin proteins in neutral waters, the daily renewal of water was deemed likely to have had a particular effect on the exudation of non-protein materials and elimination of impurities hence increased in the protein content of the isolates. Furthermore, the high protein content in acidic isolates as compared to alkaline isolates had come about due to the intensity of denaturation and higher rate of non-protein materials' exudation 
from the raw material during alkaline extraction method. Although the protein content was expected to be higher in alkaline isolates due to the high solubility of proteins in higher $\mathrm{pH}$ values (the increase in $\mathrm{pH}$ towards alkaline values causes the separation and dissolution of more protein) as compared to the protein content in acidic isolates, protein levels were higher in acidic method (for the milder denaturation) as compared to the alkaline method in which the denaturation occurred more fiercely hence the higher exudation of non-protein materials from the complex and impure matrix of the initial raw materials (V. ervilia grain). It seems that the high rate of nonprotein materials' exudation in severe denaturation (alkaline method) interfered with the protein exudation from raw materials hence preventing the complete exudation of protein.

Moisture (water holding and adsorption capacity): Water constitutes a vast fraction of the foodstuff ingredients. Measurement of the amount of water or moisture in foodstuff plus determining the purity is of great importance in terms of the foodstuff storability and spoilage for the effect they have on the amount of water activity rates. In protein products, the amount of moisture or water in the initial burger mixture is one of the important and essential factors during burger molding stage. In case the normal water content be more than the burger paste or if the amounts of water adsorbents and preservatives like protein ingredients become low, then the burger would not be well formed and the initial mixture would appear in an unfavourable form. In addition, the low quantity of water adsorbents and connectives in formulation can cause disorders in the regulation of moisture, durability and creation of a coherent texture in the final product. The analysis of the obtained results indicated that the method type of protein extraction from $V$. ervilia grain significantly influenced the moisture levels of all the plant-based protein products produced in a $5 \%$ level $(\mathrm{P}<0.05)$. As it can be observed in Table 3 , plant-based protein products in the formulation of which use had been made of isolates produced based on salt-dialysis and micelleshad lower moisture contents with a significant difference in respect to the other two treatments (plant-based protein products formulated with isolates produced based on alkaline and acidic methods). The reason for the low moisture content of these treatments could be ascribed to the high protein rates in these treatments. In other words, it could be stated that proteins are amongst the most effective water preservatives and adsorbents in burger formulations and capable of adsorbing a larger amount of water existent in the formulation as a result of which the final product would have a lower moisture rate. Due to their possession of charged and polar side chains, proteins are amongst the most important ingredients increasing the water adsorption and preservation in food systems $(22,23)$. Polar and charged amine acids in proteins react with water molecules for their being hydrophilic and adsorb water. These charged amine acids are the most important factors determining the amount of water retention capacity of the proteins in such a manner that protein isolates with polar amine acids and more polar groups act more successfully in adsorbing and retaining water (24). Besides the protein isolates' amounts, functional characteristics of protein isolates (water adsorption and retention properties) are also effective on the water and moisture adsorption and retention from the product. The protein isolates produced based on salt-dialysis and micelles method have higher water adsorption capacity in contrast to the protein isolates produced based on alkaline and acid methods. In protein isolates produced based on alkaline and acid methods, the protein isolates' purity is reduced for the acidic and basic $\mathrm{pH}$ values hence the effects stemming from the intensity of protein denaturation. Such a purity reduction negatively influences the isolate solubility hence the water adsorption and retention properties of the protein isolates. In other words, the high denaturation degrees in acidic and basic pH values causes the impurities and non-protein materials (polysaccharides, dissolved sugars, carbohydrates and raw fiber) to more intensively exit the initial $V$. ervilia extract. The exist of the majority of the impurities from the raw material causes a reduction in the purity percentage of protein isolate, the result of which would be lowering of protein isolate's solubility hence lowering of the water adsorption and retention trait of the isolate (11). In other words, it can be stated that the higher water adsorption and solubility of proteins depends on the denaturation degree of them during extraction. Due to the fact that protein isolates extracted based on saltdialysis and micelles-based sequestration undergo the lowest denaturation during protein extraction, their properties of water adsorption and retention is a lot higher than those of the protein isolates produced based on alkaline and acidic methods. Adebowale et al (25) and Paredes-Lopez (14) stated, respectively, for protein isolates of Bambara beans and soybean and peas that the water adsorption and retention of protein isolates was more increasingly higher in micellessequestration extraction method as compared to alkaline-sequestration in isoelectric point. These researchers related the high rate of water adsorption in micelles-sequestration to the greater hydrogen bonds with water that form by the side chains and polar groups in contact on the micellested protein surface. This is while the alkaline-sequestration in isoelectric point caused the production of proteins featuring a structure that limited the protein's ability for interacting with and adsorbing of water. Put differently, proteins with a larger number of near-surface hydrophobic functional groups tended to repel more water and this held true in regard of the 
alkaline extraction method for its high denaturation intensity hence the increase in the near-surface hydrophobic functional groups. Fuhrmester and Meuser (19) expressed that the higher solubility of protein isolates extracted based on various methods of micelles and saltdialysis extraction was reflective of the idea that the extracted proteins were healthier and more natural and had not undergone much of a change (denaturation) and have preserved their functional nature and properties.

Ash: Although the amount of ash in burger increased with the increase in salt, condiment and protein isolates, no significant difference was observed in terms of ash amounts of the treatments for the application of completely similar production conditions and identicalness of the amount and type of the physicochemical properties of all the components used in the formulation as well as the absence of any significant differences in the amounts of ash in the various protein isolates of $V$. ervilia grains.

The amounts of products' oil oozes during cooking (oil adsorption and holding capacity):

The oil adsorption and retention capacity is one of the important functional properties of the proteins in such a manner that it is found playing an important role in palatal sense and preservation of the foodstuff's scent and flavor (26). In industrial terms, oil adsorption and retention reflecting the emulsification properties is considered as a desirable and important trait in the production of such products as mayonnaise sauce and protein products. In other words, the increase in nonpolar amine acids and hydrophobic groups causes an increase in oil adsorption (22). The analysis of the obtained results indicated that the method type of protein extraction from Vicia ervilia grain was significantly effective on the amount of oil discharged from all the plant-based protein products in $5 \%$ level $(\mathrm{P}<0.05)$. As it can be seen in Table 3, plant-based protein products manufactured using protein isolates extracted based on alkaline and acidic methods had lower amounts of discharged oil with a significant difference in respect to the other two treatments (plant-based protein products formulated using protein isolates produced based on salt-dialysis and micelles method). The reason for lower amount of oil discharged in these treatments could be attributed to their high oil adsorption and retention capacity. The reason for higher oil adsorption and retention capacity in methods of sequestration based on isoelectric point (alkaline and acid methods) in contrast to cold protein extraction methods (salt-dialysis and micelles sequestration) could be justified as follows: in alkaline and acidic $\mathrm{pH}$ values, protein denaturation occurred more intensively. The increase in the protein denaturation intensity caused a change in the shape and conformation of proteins that could per se cause the more accentuated presence of hydrophobic proteins and surfacing of hydrophobic parts and nonpolar side chains of amine acids (that are usually buried inside the protein structure before denaturation). In fact, $\mathrm{pH}$ variations in different environments, especially in basic environment, following which the degree and intensity of proteins' denaturation comes about could influence the shape and conformation of proteins and, finally, resulted in surfacing or concealing of water-oil attachment sites (20). A study concluded that the larger the number of nonpolar amine acids in the proteins' side chains, the higher the oil adsorption capacity (25). The high rate of oil adsorption in protein isolates meant that the non-polar amine acids were in their largest amount in the protein's spatial arrangement (nonpolar amine acids' being exposed). Therefore, the higher the oil adsorption capacity, the more prevalent the nonpolar amine acids would be in the proteins' side chains. Due to the same reason, it was better to use protein isolates in the food industry in products like desserts and mayonnaise sauce and meat products for which a large deal of oil should be used for the fact that they had higher oil adsorption capacity so that the oil existent in the formulation of the produced foodstuff could be preserved $(16,25)$ stated for protein isolates they extracted from Bambara beans and soybean and peas, respectively, that the oil adsorption and retention capacity of the protein isolates extracted based on alkaline method was higher than that of the ones extracted based on micelles sequestration with the next rank going to extraction assisted by saltdialysis; additionally, they attributed the reason for the foresaid finding to the denaturation of proteins for a higher rate in alkaline extraction methods.

Sensory and organoleptic evaluation of protein products formulated with various protein isolates of Vicia ervilia grain:

As it can be observed in Table 3, the analysis of the obtained results indicated in regard of color and texture parameters (preservation of the apparent form following cooking) that there was no significant difference between the treatments and the evidence treatment so it could be concluded that these sensory parameters were all optimal and appropriate as opined by the tasters. As for the evaluation of flavor and tenderness of the cooked product, no significant difference was evidenced between the treatments and evidence treatment. Since the proper amounts of oil and moisture played an important and considerable role in the evaluation of flavor and tenderness, the high scores given to flavor and tenderness in saltdialysis and micelles sequestration treatments could have been possibly due to the low moisture in the products as a result of their good capacity of water adsorption hence the elevation of their hydration and tenderness. Furthermore, considering the high rate of oil in these treatments, 
it could be concluded that the more the fat content of the protein products, the more their consequent tenderness. Since the scattering of the fat particles in the initial materials could influence the quality of the protein product, the method of mixing the initial materials was amongst the factors effective in the quality of fat dispersion in such a manner that the more dispersed the fat particles and the smaller their sizes, then the higher the quality of the protein product.

Investigating the microbial status of the plant-based protein products formulated with various $V$. ervilia grain protein isolates:

The investigation of the results of the microbial tests was indicative of the optimum microbial status and health of the final product. Microorganisms' growth is subject to the effect of internal and external factors, including $\mathrm{pH}$, moisture percentage, oxidation and reduction potentials, nutrients, antimicrobial ingredients, biological structure, temperature, relative humidity of the environment and the mutual effect of microorganisms. Since the burgers produced in this style were auspicious environments for growth and propagation of various kinds of microbes and fungi due to their possession of all the nutrients and nutritional compounds as well as the required moisture, they had to be kept in frozen form immediately after production till the time of use so that their quality could be maintained and their durability could be extended. As it can be seen in Table 3, all of the microbial results pertaining to the treatments were in the allowed limit specified in the above mentioned standard. In the present study, the low level of the product's microbial load could be attributed to the use of appropriate raw materials devoid of microbe and observation of all the sanitary conditions during production, use of clean and disinfected devices and equipment and storing of the final product in frozen state till use.

Investigating the products' durability six months after production:

The physicochemical, sensory and microbial properties of all the plant-based protein products were once again investigated after six months of the burgers' production. The evaluation of the results indicated that these characteristics had not undergone a tangible change during six months as compared to the preliminary results and they were still in the permissible limits specified in the standard. In addition to the pharmacological effects and its bioactive ingredients of herbs and nutritional compounds that are useful are especially useful for human health $(27,28)$.

\section{Conclusion}

The present study reveals that the high rate of fat and protein in the plant-based protein products formulated with protein isolates extracted based on salt method could be attributed to the production conditions of the isolates; the high amount of discharged oil could be ascribed to the lower oil retention and adsorption capacity; and, the low amount of the measured moisture could also be attributed to the high rate of protein (water adsorption and retention capacity) in these treatments. Considering the high rate of fat and water adsorption in these treatments, it could be stated that the higher the amount of fat and water adsorption in protein products, the higher the resulting tenderness (a sensory trait) of the final product. One important reason for the low amount of fat and protein and high amount of carbohydrate in isolates produced based on acidic and alkaline extraction as compared to the other methods was the changes resulting from denaturation intensity in these methods. It could be generally stated that the cold protein extraction methods (salt-dialysis and micelles sequestration), in contrast to the methods of isoelectric pointbased sequestration (acidic and alkaline methods), prevented the severe denaturation of the proteins and this could per se play an important and considerable role in the improvement of the physicochemical and sensory properties of plantbased burgers formulated with protein isolates.

\section{Acknowledgements}

We are grateful to Lorestan Food and Drug control lab for helpful technical assistance.

\section{Authors' contributions}

All the authors contributed equally to the work presented in this paper.

\section{Competing Interests}

The authors declared that they have no conflict of interest.

\section{References}

1. Boye J, Zare F, Pletch A. Pulse proteins: Processing, characterization, functional properties and applications in food and feed. Food research international 2010; 43(2): 414-431. https://doi.org/10.1016/j.foodres.2009.09.003

2. Haddad SG. Bitter vetch grains as a substi ute for soybean meal for growing lambs. Livestock Science 2006; 99(2-3): 221-225. https://doi.org/10.1016/j.livprodsci.2005.06.014

3. Belido L. Legumes for animal feed. http://www.hortprudue.edu/newcrop/1492/legumeanimal.html, 1994.

4. Chandi GK, Sogi DS. Functional properties of rice bran protein concentrates. Journal of Food Engineering 2007; 79:592-597. https://doi.org/10.1016/j.jfoodeng.2006.02.018

5. Karaca AC, Low N, Nickerson M. Emulsifying properties of chickpea, faba bean, lentil and pea proteins produced by isoelectric precipitation and salt extraction. Food Research International 2011; 44(9):2742-2750. https://doi.org/10.1016/ j.foodres.2011.06.012 
6. Han XZ, Hamaker BR. Partial leaching of granuleassociated proteins from rice starch during alkaline extraction and subsequent gelatinization. Starch-Stärke 2002; 54(10):454-460. $\quad$ https://doi.org/10.1002/1521379X(200210)54:10<454::AID-STAR454>3.0.CO;2-M

7. Kinsella, 1979. Functional properties of soy proteins. https://doi.org/10.1007/BF02671468

8. Fenema OR. Food Chemistry. $3^{\text {Rd }}$, Marcel Dekker Incorporation. USA.

9. RakoskyJr J. Soy grits, flour, concentrates, and isolates in meat products. Journal of the American Oil Chemists Society 1974; 51(1Part1), 123A-127A. https://doi.org/10.1007/BF02542109

10. Mondor M, Aksay S, Drolet H, Roufik S, Farnworth E, Boye JI. Influence of processing on composition and antinutritional factors of chickpea protein concentrates produced by isoelectric precipitation and ultrafiltration. Innovative Food Science \& Emerging Technologies 2009; 10(3):342-347. https://doi.org/10.1016/j.ifset.2009.01.007

11. Farhoosh R, Poorazrang $H$, Khodaparast $M M H$, Rahimizadeh M, Seyedi SM. Extraction and separation of antioxidative compounds from Salvia leriifolia leaves. Journal of Agricultural Science and Technology (JAST) 2004; 6 (1\&2), 57-62.

12. Kiosseoglou V, Paraskevopoulou A. Functional and physicochemical properties of pulse proteins. Pulse Food: Processing, Quality and Nutraceutical Applications, Elsevier Inc., London 2011; 57-90. https://doi.org/10.1016/B978-0-12-382018-1.00003-4

13. Liu LH, Hung TV, Bennett L. Extraction and characterization of chickpea (Cicer arietinum) albumin and globulin. Journal of Food Science 2008; 73(5),299-305. https://doi.org/10.1111/j.1750-3841.2008.00773.x

14. ParedesLópez O, Ordorica Falomir C, OlivaresVázquez MR. Chickpea protein isolates: physicochemical, functional and nutritional characterization. Journal of Food Science 1991; 56:726-729.https://doi.org/10.1111/j.1365-2621.1991.tb05367

15. Cordero-De-Los-Santos MY, Osuna-Castro JA, Borodanenko A, Paredes-López O. Physicochemical and functional characterisation of amaranth (Amaranthus hypochondriacus) protein isolates obtained by isoelectric precipitation and micellisation. Food Science and Technology International 2005; 11(4),269-280. https://doi.org/10.1177/1082013205056491

16. Stone AK, Karalash A, Tyler RT, Warkentin TD, Nickerson MT. Functional attributes of pea protein isolates prepared using different extraction methods and cultivars. Food Research International 2015; 76: 31-38. https://doi.org/10.1016/j.foodres.2014.11.017

17. Shahraki F, Mortazavi A, Haddad Khodaparast MH, Milani A, Hassary Nejad,M. A, and Hossein Zadeh A. examining the quality and purity ofthe protein extracted from the vegetable seed of Lathyrus and optimizing it using the response level method, The second national seminar on food security, Islamic Azad University of Savadkooh, 2013.

18. Bakhshi Moghaddam F, Mortazavi A, Milani A, Hashemi M. Evaluation of Nitrogen fraction diversity and functional characteristics of protein isolate of chickpea. Magazine of Innovation in Science and Technology of Food. 2013; 4: 93103.

19. Fuhrmeister $\mathrm{H}$, Meuser F. Impact of processing on functional properties of protein products from wrinkled peas. Journal of Food Engineering 1996; 56(2-3):119-129. https://doi.org/10.1016/S0260-8774(02)00241-8

20. Ravaghi Darani M. Effect of production procedures and drying step on functional properties of soy protein concentrates produced from industrial soyflours. M Sc. Thesis. Ferdowsi University of Mashhad Faculty of Agriculture (in Farsi), 2010.

21. AAluko RE, Yada RY. Structure-function relationships of cowpea (Vigna unguiculata) globulin isolate: influence of $\mathrm{pH}$ and $\mathrm{NaCl}$ on physicochemical and functional properties. Food Chemistry 1995; 53(3): 259-265. https://doi.org/10.1016/0308-8146(95)93931-G

22. Jitngarmkusol S, Hongsuwankul J, Tananuwong, K. Chemical compositions, functional properties, and microstructure of defatted macadamia flours. Food $\begin{array}{llll}\text { Chemistry } & 20081 & 110(1): & 23-30 .\end{array}$ https://doi.org/10.1016/j.foodchem.2008.01.050

23. Lawal OS, Adebowale KO, Ogunsanwo BM, Sosanwo OA, Bankole S. A. On the functional properties of globulin and albumin protein fractions and flours of African locust bean (Parkia biglobosa). Food chemistry 2005; 92(4): 681-691. https://doi.org/10.1016/j.foodchem.2004.08.043

24. Sathe SK, Deshpande SS, Salunkhe DK. Functional properties of winged bean [Psophocarpus tetragonolobus (L.) DC] proteins. Journal of Food Science 1982; 47(2): 503509. https://doi.org/10.1111/j.1365-2621.1982.tb10112.x

25. Adebowale KO, Lawal OS. Comparative study of the functional properties of bambarra groundnut (Voandzeia subterranea), jack bean (Canavalia ensiformis) and mucuna bean (Mucuna pruriens) flours. Food Research International $\quad 2004 ; \quad 37(4)$ : $355-365$ https://doi.org/10.1016/j.foodres.2004.01.009

26. Kinsella J E. Functional properties of soy proteins. Journal of the American Oil Chemists' Society 1979; 56(3Part1):242 258. https://doi.org/10.1007/BF02671468

27. Faryadian S, Sydmohammadi A, Khosravi A, Kashiri M, Faryadayn P, Abasi N. Aqueous extract of Echium amoenum elevate CSF Serotonin and Dopamine level in depression rat. Biomed Pharmacol J 2014; 7(1): Available from: http://biomedpharmajournal.org/?p=2875

28. Valadi A, Nasri S, Abbasi N, Amin G. Antinociceptive and anti-inflammatory effects of hydroalchoholic extract of Anethum graveolens L. seed. JMP 2010; 2 (34):124-130. 